http://journal.nafo.int

J. Northw. Atl. Fish. Sci., Vol. 9: 97-102

\title{
Slope Water Intrusion to the Great South Channel During Autumn, 1977-85
}

\author{
David G. Mountain \\ National Marine Fisheries Service, Northeast Fisheries Center \\ Woods Hole Laboratory, Woods Hole, Massachusetts 02543, USA \\ Marianna Pastuszak \\ Sea Fisheries Institute \\ 81-345 Gdynia, Poland \\ and \\ Donna A. Busch \\ National Marine Fisheries Service, Northeast Fisheries Center \\ Narragansett Laboratory, Narragansett, Rhode Island, 02882,USA
}

\begin{abstract}
Measurements of water properties in the Great South Channel (GSC) made on 35 surveys between 1977 and 1985 indicate an intrusion of high salinity water in the autumn of most years. The intrusion represents an influx of slope water. It is most evident near bottom, but high salinity values are found throughout the water column. In some years the intrusion can be traced through the channel to the north side of Georges Bank. Larvae of offshore, warm-water fish species found in the high salinity intrusion support reports that the presence of these larvae is associated with an influx of slope water through the channel. The influx is likely to be associated with the seasonal shelfward movement of the shelf/slope front during the autumn. While the extent of the influx may be modified by Gulf Stream rings located south of the channel region, the phenomenon does not appear to be caused by rings. The influx of slope water across the shelf and to GSC suggests a seasonal reduction in the transport of Georges Bank water westward past Nantucket Shoals.
\end{abstract}

\section{Introduction}

Great South Channel (GSC) is a topographic depression between shallower Georges Bank to the east and Nantucket Shoals to the west (Fig. 1). It has a sill depth of about $70 \mathrm{~m}$ separating the Gulf of Maine to the north from the Atlantic Ocean to the south. On Georges Bank the mean circulation of water includes an eastward flow along the northern slope of the bank that turns around the eastern end of the bank to form a westward flow along the southern side of the bank (Butman et al., 1982). While most of this flow continues westward on the outer shelf past Nantucket Shoals (Beardsley et al., 1985), a portion of it turns north through GSC to form a clockwise gyre on the bank. The existence of a gyre component to the circulation is believed important to fish populations on the bank because it provides a retention mechanism to keep the planktonic fish eggs and larvae on the bank where food and environmental conditions are conducive to survival (Iles and Sinclair, 1982). Limited current meter measurements have suggested that the circulation of water through GSC is greatest in the summer and autumn when the flow around the rest of the bank is also at a maximum (Butman and Beardsley, 1987). The interannual variability of the flow in the channel is not known.

Bolz and Lough (1984) analyzed plankton data from Georges Bank and used the distribution of fish larvae associated with the warm waters offshore to infer aspects of circulation in the GSC region. They showed a northward influx of larvae through GSC and onto the northern side of Georges Bank during the autumn-winter periods of 1971-77 and attributed this influx to an intrusion of slope water through the channel, with the larvae being mostly passive drifters. The intrusion was greatest in 1973 and 1974, and was least developed in 1971 and 1972. In years when a greater influx of offshore fish larvae to the channel and the southern side of Georges Bank was observed, Bolz and Lough (1984) also found an increase in abundance of larvae of fish species associated with the Bank. They hypothesized that a greater influx of slope water resulted in a more effective retention of water on the bank and thus in less advective loss of eggs and larvae from the Georges Bank fish species. Bolz and Lough (1984) used data from larval herring surveys conducted between September and February, which included temperature data 


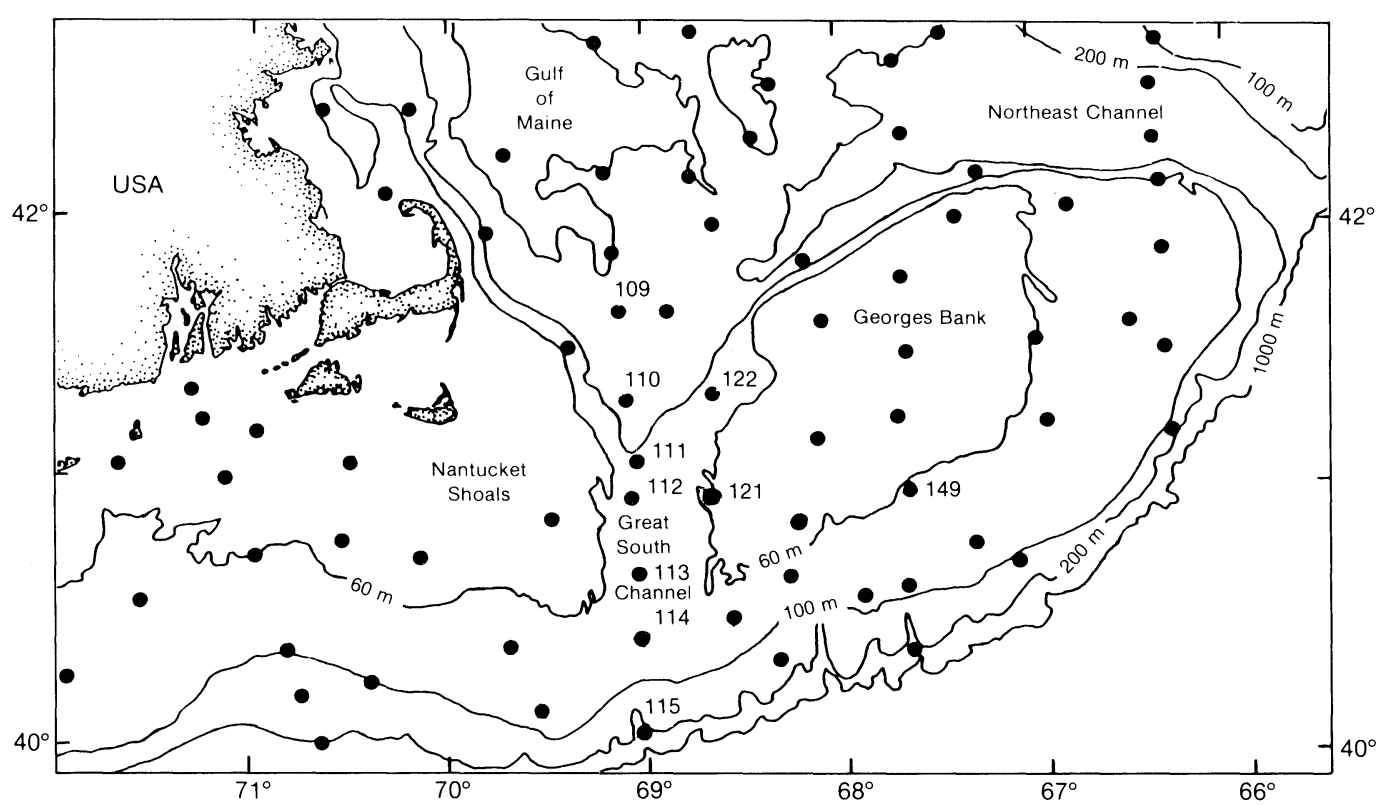

Fig. 1. Locations of MARMAP. hydrographic/plankton stations in the Great South Channel region.

but only occasional salinity measurements. Consequently they were not able to identify an actual influx of slope water properties entering through GSC. This report investigates the influx of slope water to the GSC using a data set which includes both hydrographic measurements and ichthyoplankton samples.

\section{Materials and Methods}

Hydrographic data from the GSC region (Fig. 2) were obtained from 35 Marine Resources, Monitoring, Assessment and Prediction (MARMAP) surveys (Sherman, 1980) conducted between 1977 and 1985. The portion of the MARMAP station grid near GSC is shown in Fig. 1, although not all of the stations were occupied on each survey. The hydrographic observations were made at up to 15 standard depths using water bottles with reversing thermometers. The temperature data are accurate to $\pm 0.02^{\circ} \mathrm{C}$. In most cases water samples were returned to the laboratory and salinity determinations were performed on a Guildline Autosal with an accuracy of at least $\pm 0.01 \%$. On a few cruises the determinations were done at sea using a bench salinometer with an accuracy of $\pm 0.02 \%$.

Icthyoplankton samples were obtained from double oblique tows using a $61-\mathrm{cm}$ bongo frame fitted with 505 and 333 micron mesh nets (Sibunka and Silverman, 1984). Fish eggs and larvae were sorted from the 505 micron samples at the Morski Instytut Rybacki in Szczecin, Poland using a protocol described by Jossi and Marak (1983). Ichthyoplankton data for 18 surveys from 1977 to 1980 are considered in this analysis. To compare with the results of Bolz and Lough (1984),

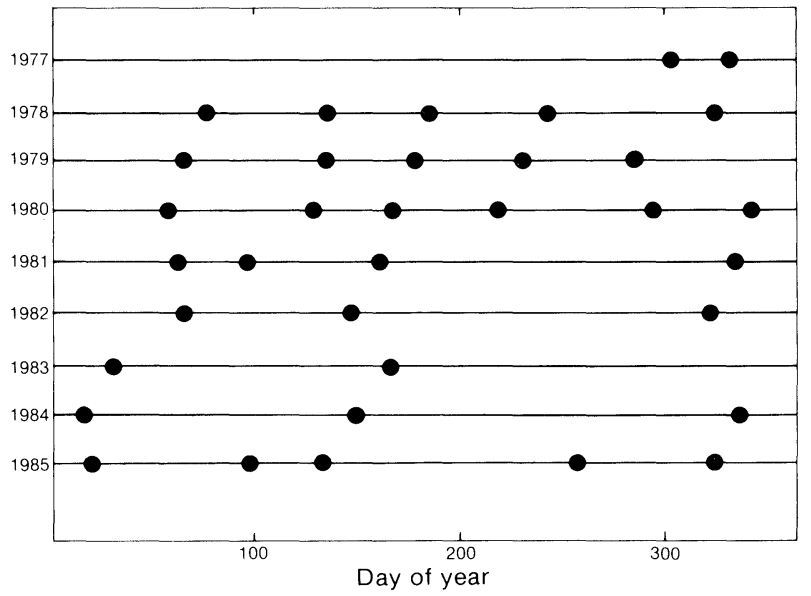

Fig. 2. Timing of hydrographic and plankton sampling in the Great South Channel region for MARMAP cruises during 1977-85.

larvae of six warm water fish species or groupings of species were used as indicators of the influx of offshore waters to the shelf in the GSC region. They were Bothus sp., Syacium sp., Syacium papillosum, Benthosema glaciale, Ceratoscopelus maderensis and Paralepididae. They were chosen because their planktonic stages generally are found in the MARMAP surveys along the outer edge of the shelf only in the region of the shelf/slope front.

\section{Results}

\section{Distribution of water properties}

The presence of slope water in GSC is most evident from the salinity of the water in the channel. The 
temperature contrast between shelf water and slope water is comparable to the seasonal vertical temperature difference in both areas $\left(\approx 10^{\circ} \mathrm{C}\right)$. This makes it difficult to use temperature to distinguish between local vertical mixing and an influx of slope water as the cause of unusual properties in the channel. For salinity, the shelf water-slope water contrast is about 3-5 times the vertical difference and, thus, salinity offers a better indicator of a contribution of slope water properties.

To indicate the intrusion of slope water into the channel region, the salinity data from each cruise were portrayed in two ways: by a north-south vertical section through the channel (stations 109-115 in Fig. 1) and by the spatial distribution of average salinity in the upper $25 \mathrm{~m}$ of the water column. This near surface layer was used to allow the shallow regions of Georges Bank to be included in the analyses.

The salinity distributions were characterized by two patterns, as illustrated in Fig. 3 for 1979. For nearly all surveys that were not in the autumn of the year, the section of salinity along the axis of the channel showed the salinity gradient of the shelf/slope front intersecting the bottom between 80 and $100 \mathrm{~m}$ along the outer (southern) edge of the shelf (Fig. 3A). On these surveys the salinity values in the channel were generally less than $33 \%$. For surveys during the autumn, higher salinity values generally intruded northward into the channel, particularly at depth, indicating a contribution of the higher salinity slope water from offshore. For example in October 1979 (Fig. 3B) the $34.00 \%$ isohaline extended nearly across the sill into the Gulf of Maine.

The spatial distributions of near surface salinity (Fig. 4A-F) showed similar patterns. During most of the year the horizontal salinity gradient of the shelf/slope front ran along the outer edge of the shelf, as in May 1979 (Fig. 4A). During the autumn of 1979 (Fig. 4B), however, a tongue of higher salinity water was evident extending through GSC. A temperature-salinity diagram of the 0-25 $\mathrm{m}$ average water properties for the autumn of 1979 is shown in Fig. 5. The stations in Georges Bank generally had salinity of $<32.6 \%$. The surface layer at station 115, the furthest offshore, had a salinity of $35.8 \%$ and represented unaltered slope water. The stations in GSC and along the southern edge of the bank at the shelf/slope front were on a mixing line between the slope water and the Georges Bank water. In GSC the surface layer, values at stations 112 and 111 represent a mixture of water comprised of about $30 \%$ slope water and $70 \%$ Georges Bank water.

Determining what constitutes "high" salinity to indicate slope water input to the channel is somewhat arbitrary, because Georges Bank water undergoes seasonal and interannual variation in salinity. The charac-

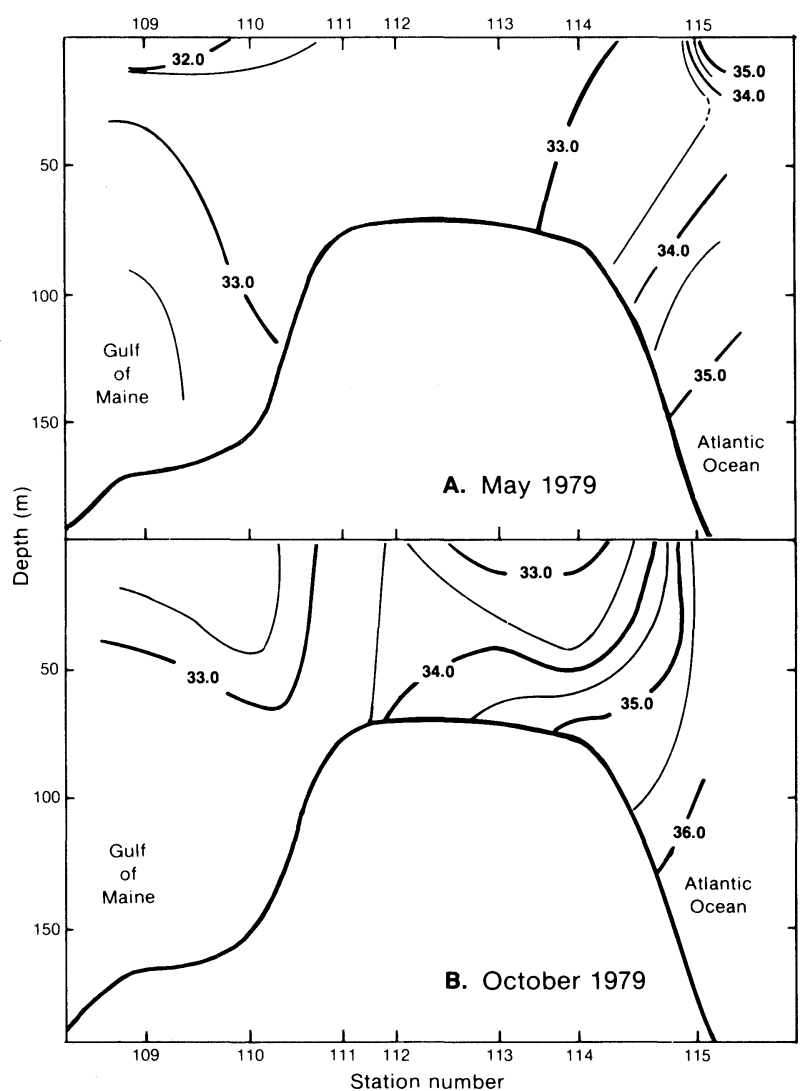

Fig. 3. Vertical section of salinity (\%o) along the axis of Great South Channel in (A) May 1979, and (B) October 1979.

teristic seasonal cycle of salinity has minimum values in the summer, maximum values in the winter and a seasonal range of about $0.5 \%$ (Hopkins and Garfield, 1981). This seasonal variation is similar on all parts of the bank (Flagg, 1987) and should not contribute to spatial differences in salinity. Therefore, a consistent indicator of slope water input is provided by comparing the salinity inside the mouth of the channel (station 113, 76 m depth) with that at a comparable depth along the southern side of Georges Bank (station 149, $67 \mathrm{~m}$ depth). With no input of slope water the salinity at the two stations should be about equal. The stations were chosen because of their locations (see Fig. 1) and because both were occupied on 31 of the 35 surveys, with one survey having occupied the stations twice. Since the vertical sections indicate that intrusions of slope water are most evident below $50 \mathrm{~m}$ (e.g. Fig. 3B), the average salinity below $50 \mathrm{~m}$ was used to compare salinity between stations. The salinity difference (station 113-149) was plotted against day of the year in Fig. 6. With only two exceptions, all of the differences between stations from day 280 to 340 were greater than $0.4 \%$ and at all other times, less than $0.4 \%$. This means that in October and November the water in the channel is substantially more saline than that on the south side of the bank, suggesting an influx of slope 

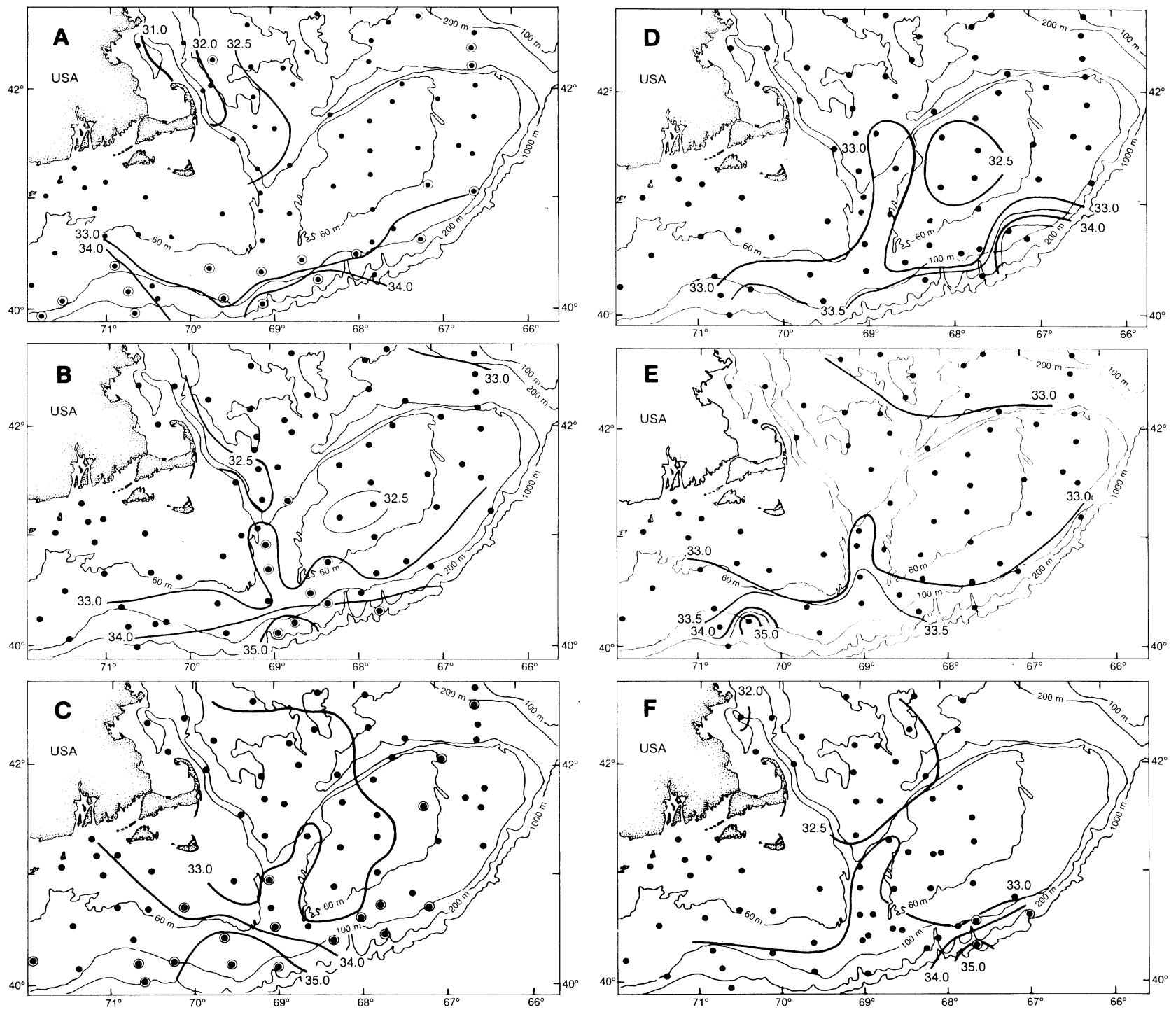

Fig. 4. Average salinity (\%o) in 0-25 m for (A) May 1979, (B) October 1979, (C) October 1980, (D) November 1982, (E) November 1985, and (F) August 1980. For the cruises in 1979 and 1980 the stations at which larvae of the selected warm water fish species were found are circled.

water during that period. A review of other stations on the bank revealed that the exception to this relationship which occurred in January 1985 was more likely the result of low salinity at station 149 than of high salinity water in the channel. The other exception was a small salinity difference in October 1978.

The intrusions of high salinity water that occurred in the autumn of 1977 and 1984 extended only into the southern side of the channel, to station 113 . In the autumn of 1980,1982 and 1985 the intrusions extended through the channel (Fig. 4C-E), similar to the 1979 case (Fig. 4B). The only intrusion of higher salinity water to GSC observed outside of the autumn period occurred in August 1980 (Fig. 4F). Then the salinity feature extended through the channel toward the northern side of Georges Bank, but the salinity contrast with the bank waters was not large $(\approx 0.30 \%$ ) and did not stand out in the salinity differences shown in Fig. 5.

\section{Ichthyoplankton distributions}

To test the conclusions of Bolz and Lough (1984) that the presence of larvae of warm water fish species in GSC are associated with the influx of slope water to the channel, the occurrence of larvae for any of the six selected warm water fish was plotted with the distribution of salinity for 18 surveys from 1977 to 1980 . The larvae were found almost exclusively near the higher salinity waters in the shelf/slope frontal region aiong the outer edge of the shelf, as illustrated in Fig. 4A-C and $4 \mathrm{~F}$. The larvae were also observed in the region of Northeast Channel where slope water enters the Gulf of Maine at greater depths (Ramp et al., 1985). The only 


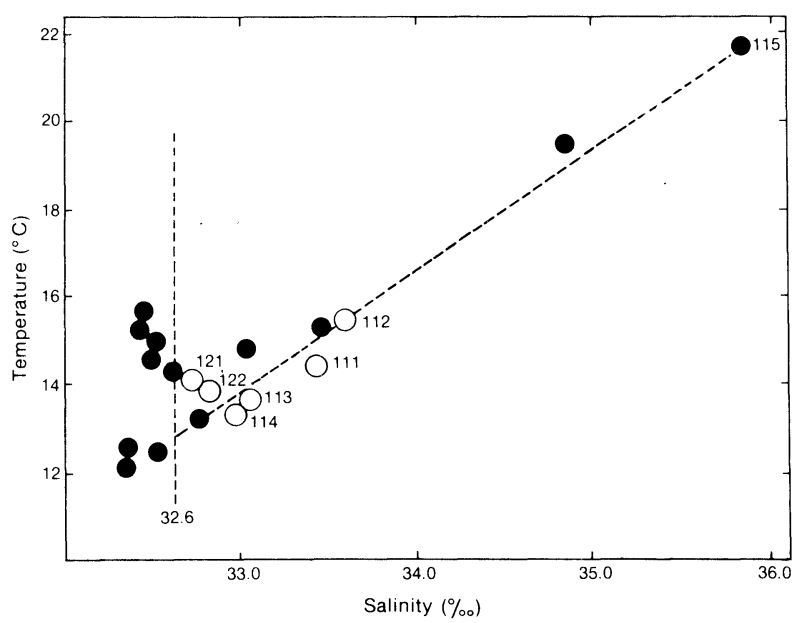

Fig. 5. Temperature-salinity $\left({ }^{\circ} \mathrm{C} ., \%\right.$ \% diagram for the $0-25 \mathrm{~m}$ average water properties observed in October 1979. Numbers refer to stations shown in Fig. 1. Stations in Great South Channel are indicated by open circles.

observations of warm water larvae in GSC were in October 1979 (Fig. 4B) and October 1980 (fig. 4C) and were associated with the influx of slope water properties to the channel, as shown by the salinity distribution in the figures.

\section{Discussion}

The salinity differences shown in Fig. 6 indicate that there is a consistent influx of high salinity slope water to GSC in the autumn of the year. The association of the larvae of warm water fish species with the high salinity water supports the conclusions of Bolz and Lough (1984). Combining the results of the two data sets indicate that an intrusion of slope water to GSC occurred during the autumn of each year from 1971 to 1985 , with the exception of 1978 and 1981 (no data were available for 1983). In six of those years $(1973,1974$, 1979, 1980, 1982 and 1985), as indicated by either high salinity or by observation of larvae from offshore, the intrusion extended through the channel to the northwest side of Georges Bank.

Butman and Beardsley (1987) reported an increase in the northward transport of water through the eastern side of GSC during the summer and autumn of 1978. They showed that the increase occurred at the same time and it was in proportion to an increase in transport observed all around the bank. The greaterflow through the channel by itself, however, would not necessarily result in or require an input of high salinity water from offshore.

Two other aspects of the seasonal oceanographic conditions on Georges Bank are likely to contribute to the influx of slope water properties to GSC during the autumn. The surface manifestation of the shelf/slope

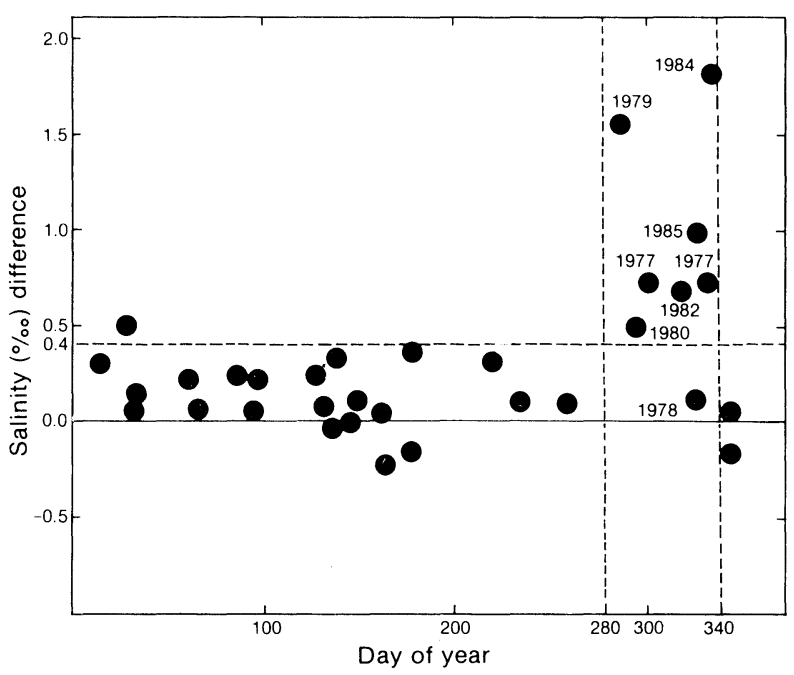

Fig. 6. Difference in average salinity (\%o) below $50 \mathrm{~m}$ between station 113 in Great South Channel and station 149 on the south side of Georges Bank (see Fig. 1 for locations) versus day of the year for all cruises on which both stations were occupied during 1977-85. Positive values indicate higher salinity in Great South Channel.

front migrates shoreward about $80 \mathrm{~km}$ from February, when it is farthest offshore, to October when it is nearest to the shelf break (Butman and Beardsley, 1987). This movement of the front means that the high salinity slope water is in closest proximity to the channel in the autumn. In addition, along the southern side of Georges Bank the cross-isobath current component reaches a maximum in the on-bank direction during September and October at mid-depth $(45 \mathrm{~m})$ and at greater depths (75 and $84 \mathrm{~m}$ ) turns to be on-bank in November (Butman and Beardsley, 1987). If the dynamics controlling this cross shelf flow apply to the shelf south of GSC (100 km to the west), the deeper areas in the channel would provide an avenue for the on-bank flow at depth to bring offshore waters into the channel region. Then the onshore movement of the shelf/slope front together with the on-bank tendency of the subsurface currents, could contribute to the observed intrusion of high salinity water to GSC during the autumn.

Satellite imagery indicated that during the autumn 1978 survey a large Gulf Stream meander was present in the Slope Water region southwest of GSC. During the autumn 1981 survey a Gulf Stream ring was similarly observed. In both cases the imagery showed that shelf water was being entrained by the ring or meander from the edge of the shelf south of the channel $\left(68^{\circ}\right.$ $69^{\circ} \mathrm{W}$ ). The influence of the ring and the accompanying entrainment of shelf water would counteract a tendency for the high salinity offshore water to intrude the channel and this in fact could be responsible for the intrusion not being observed during the autumn surveys of 1978 and 1981. 
A further review of satellite imagery in other years did not indicate a consistent relationship between the extent of the high salinity intrusion to GSC and the occurrence of Gulf Stream rings. During the observations in autumn of $1977,1979,1980$ and 1982 rings were located southeast of the channel region. The shelfward flow on the west side of the rings could have driven high salinity offshore water onto the shelf and into GSC. In 1984, however, no ring was near the channel region during the autumn observations. In the autumn of 1985 a ring was southwest of the channel, which was more likely to have resulted in entrainment of shelf water off the shelf than to cause an influx of slope water to the shelf. Yet in both 1984 and 1985 an influx of slope water to GSC was observed (Fig. 6). Conversely, during observations at other times of the year, rings have been located southeast of the channel region while no indication of a slope water influx to the channel was found (Fig. 6). Gulf Stream rings may modify the extent of the autumn influx of slope water to GSC, but they do not appear to be a cause of the phenomenon.

During most of the year, water from the south side of Georges Bank flows westward south of Nantucket Shoals toward the Middle-Atlantic Bight (Beardsley et al., 1985). This westward flow represents the major path by which water leaves the bank. When slope water properties intrude across the shelf and into GSC, the westward transport past Nantucket Shoals is comprised largely of slope water. Then the westward transport of Georges Bank shelf water is interrupted or at least greatly reduced. For example in the vertical section though GSC during October 1979 (Fig. 2B) there was essentially no area of pure shelf water (salinity $<33.00 \%$ ) that could have been flowing westward. Measurements of the westward flow of water past Nantucket Shoals (Beardsley et al., 1985) show that during November 1979 , the temperature and salinity throughout the water column across the shelf to at least the 65 $\mathrm{m}$ isobath (the mooring $\mathrm{N} 2$ ) increased to values that indicate the presence of a large fraction of slope water $\left(>15^{\circ} \mathrm{C}\right.$ and $>34.00 \%$ ).

The seasonal interruption of the westward flow of shelf water from Georges Bank has two important implications. First, the water properties in the shelf region south of New England are directly affected. The influence of slope water would advance shoreward to near the $60 \mathrm{~m}$ isobath west of GSC while to the east on Georges Bank it would be limited to near the shelf edge. Second, with a major exit of water from Georges Bank reduced, the residence time of water on the bank would likely be increased. This could have positive implica- tions for the survival of the plankton populations on the bank as suggested by Bolz and Lough (1984).

\section{Acknowledgements}

The authors thank W. Smith of the National Marine Fisheries Service, Northeast Fisheries Center, Sandy Hook, New Jersey, for providing the ichthyoplankton data used in this report.

\section{References}

BEARDSLEY, R. C., D. C. CHAPMAN, K. H. BRINK, S. R. RAMP, and R. SCHLITZ. 1985. The Nantucket Shoals flux experiment (NSFE79). Part I: a basic description of the current and temperature variability. J. Phys. Oceanogr., 15(6): 713-748.

BOLZ, G. R., and R. G. LOUGH. 1984. Retention of ichthyoplankton in the Georges Bank region during the autumnwinter seasons, 1971-77. J. Northw. Atl. Fish. Sci., 5: 33-45.

BUTMAN, B., R. C. BEARDSLEY, B. MAGNELL, D. FRYE, J. A. VERMERSCH, R. SCHLITZ, R. LIMEBURNER, W. R. WRIGHT, and M. A. NOBLE. 1982. Recent observations of the mean circulation on Georges Bank. J. Phys. Oceanogr., 12(6): 569-591.

BUTMAN, B., and R. C. BEARDSLEY. 1987. Long-term observations on the southern flank of Georges Bank. Part I: a description of the seasonal cycle of currents, temperature, stratification, and wind stress. J. Phys. Oceanogr., $17(3)$ : 367-384.

FLAGG, C. N. 1987. Hydrographic structure and variability. In: Georges Bank. Richard H. Backus and Donald W. Bourne (eds.), MIT Press, Cambridge, MA, 593 p.

HOPKINS, T. S., and N. GARFIELD III. 1981. Physical origins of Georges Bank water. J. Mar. Res., 39: 465-500.

ILES, T. D., and M. SINCLAIR. 1982. Atlantic herring: stock discreteness and abundance. Science, 215: 627-633.

JOSSI, J. W., and R. R. MARAK. 1983. MARMAP plankton survey manual. NOAA Tech. Memo., NMFS-21: $258 \mathrm{p}$.

RAMP, S., R. SCHLITZ, and W. R. WRIGHT. 1985. The deep flow through Northeast Channel, Gulf of Maine. J. Phys. Oceanogr., 15(12): 1790-1808.

SHERMAN, K. 1980. MARMAP, a fisheries ecosystem study in the Northwest Atlantic: fluctuations in ichthyoplanktonzooplankton components and their potential impact on the system. In: Advanced concepts in ocean measurements for marine biology, F. P. Diemer, F. J. Vernberg and D. Z. Mirkes (eds.), Belle W. Baruch Inst. Mar. Biol. and Coastal Res, Univ. S. Carolina Press, Columbia, p. 9-37.

SIBUNKA, J. D., and M. J. SILVERMAN. 1984. MARMAP Surveys of the continental shelf from Cape Hatteras, North Carolina, to Cape Sable, Nova Scotia (1977-1983). Atlas No. 1, Summary of Operations. NOAA Tech. Memo., NMFS-F/NEC-33: $306 p$. 